ИЗВЕСТИЯ АКАДЕМИИ НАУК ЭСТОНСКОИ ССР. ТОМ VIII СЕРИЯ БНОЛОГИЧЕСКАЯ, 1959, № 4

\title{
РАСТЕНИЯ-НОВООБРАЗОВАНИЯ ПШЕНИЦЫ, ПОЛУЧЕННЫЕ ИЗ ЛИШЕННЫХ ЗАРОДЫША ЗЕРНОВОК, И НЕКОТОРЫЕ ИХ МОРФОФИЗИОЛОГИЧЕСКИЕ ОСОБЕННОСТИ
}

\author{
о. Ф. МИХАИЛОВ, \\ кандидат биологических наук
}

T. OРАB

Проблема адвентивной эмбрионии представляет собой один из ннтереснейших разделов экспериментальной эмбриологии, так как ее разработка может дать ответы на целый ряд важных вопросов теории и практики становления формы и функции. Прямое отношение к этой проблеме имеєт также образование адвентивных зародышей при культивировании различного типа тканей растений in vitro. Большой интерес представляют, наконец, морфофизиологические особенности растений-новообразований, получаемых из адвентивных почек, особенно таких, которые закладываются в культуре ряда специализированных тканей, например в питательных тканях семядолей и эндосперма.

В последние годы авторами этой статьи опубликована серия работ, посвященных вопросу новообразований органов и целых зародышей при культивировании изолиғованных семядолей и эндосперма (Мнхайлов, 1951, 1952, 1957а, 19576, 1958, 1959; Орав, 1959). В этих работах рассматривается ряд специальных вопросов, связанных с получением адвентивных зародышей, выращиванием растений-новообғазований и изучением их морфогенеза.

В данной статье рассматривается возможность получения растений-новообразований из адвентивных почек пшеницы, образующихся в зерновках, лишенных зародышей. Выбор объекта - изолированного эндосперма - был обусловлен тем значением, которым обладают его ткани и весь орган в целом в пғоцессе формирования нормального зародыша и последующего развития растения на первых этапах онтогенеза.

Авторы статьи придерживаются той точки зрения, которая утверждает, что эндосперм (Презент, 1948) и семядоли (Мнхайлов, 1952) выполняют особую биологическую функцию как своеобразные биологические менторы, обеспечивающие формирование видовых и сортовых признаков у развивающегося растения. Наряду с этим мы разделяем взгляды С. Г. Навашина (1898) и В. Г. Александрова (1937) о зародышевой природе эндосперма, т. е. рассматриваем его как недифференциғованный второй зародыш, который в процессе эволюцни трансформировался в специальный орган питания основного зародыша.

Эксперименты, выясняющие регенерационные свойства эндосперма, как справедливо отмечает Я. С. Модилевский (1950), являются косвенным даказательством зародышевой природы этого органа.

В силу вышеизложенного мы считаем, что изученне регенерационной и репродукvионной способности эндосперма представляет несомненный интерес как с точки зрения теоретической, так и для селекционной практики. Опытами в этом направлении занимались немногие биологи. Из наиболее ранних исследований нам известна, например, работа Т. Блоцишевского (Blociszewski, 1876), который занимался дальней- 
щей разработкой и углублением опытов Ф. Ван-Тигема (Van Tieghem, 1873), изучавшего возможность восстановления целого растения из отдельных частей зародыша. Наряду с этим, Блоцишевский исследовал возможность получения целого растения и из изолированного эндосперма. На основании многочисленных опытов этот автор ирнходит к выводу, что как семядоли (безэндосперменных семян), так и эндосперм не являются образованиями, лишенными потенциальных эмбриональных возможностей, и, будучи изолированными от зародыша, при определенных условиях могут образовывать корни.

В работе другого автора - К. Пуриевича (Puriewitsch, 1898), отмечается, что эндосперм не является мертвым запасом питательных веществ и, будучи изолированным, способен выделять продукты ферментативной деятельности.

Из более поздних работ следует отметить- исследования Я. С. Модилевского (1950), Е. Петру и Р. Ржетовского (Petrū, Řetovsky̆, 1956) и др.

С точки зрения пюоблемы, изучаемой нами, большой интерес представляют исследования Модилевского, который приводит данные по регенерации изолированного эндосперма кукурузы. Автор отмечает, что при определенном возрасте эндосперм кукурузы способен к образованию каллюса, в редких случаях - корешков и еще реже - почки с листьями. Автор приводит единственный случай образования адвентивной почки у изолированного эндосперма кукурузы. $\mathrm{K}$ сожалению, вырастить растение из этой почки не удалось, так как оно скоро погибло. Модилевский отмечает, что этот случай заложения адвентивной почки у эндосперма подкрепляет взгляды на эндосперм как на второй зародыш, возникший половым путем.

\section{Опыты по культивированию изолированного эндосперма}

В целях выяснения регенерационной и репродукционной способности изолированного эндосперма, нами были использованы зерновки трех яровых сортов мягкой пшеницы Triticum vulgare, относяшихся к различным подвидам и обладающих рядом морфофизнологических особенностей.

1. Диамант (var. milturum), характеризующийся красным безостым колосом и красной зерновкой. Являясь среднеспелым, сорт этот отличается хорошей урожайностью и высокой устойчивостью против полегания и осыпания.

2. Каука (var. lutescens), выведенный Иыгеваской селекционной станщией. Обладает белым безостым колосом и красной зерновкой. По хозяйственным показателям близок к Диаманту, но превышает его по урожайности. Вегетационный период несколько длиннее.

3. Московка (var. grecum), характеризуется белым остистым колосом и белой зерновкой. Обладает повышенной кустистостью и очень прочным неполегающим стеблем. Являясь среднепоздним сортом, Московка в наших контрольных опытах по длине своего вегетационного периода оказалась близкой к Диаманту.

Работа проводилась на кафедре генетики и дарвинизма и на Биологической станции Тартуского государственного университета.

\section{Методика опытов}

Предварительно отобранные крупные, хорошо наполненные зерновки замачивались в течение 24 часов в водопроводной воде комнатной температуры. Замачивание благопрнятствовало последующей операции, т. е. отделению зародыша от эндосперма,

Непосредственно перед операцией семена промывались разбавленным спиртом и момещались в стернльную посуду. 
Сам процесс изоляции эндосперма производился в стерильных условиях с помощью препаровальной иглы, которой сравнительно легко удалялисъ зародыш и щнток (рис. 1). Изолированный таким образом эндосперм слегка обжигался на пламени спиртовки и помещался на 1 час в чашку Петри для лучшей подсушки опернрованной поверхности. Через час изолянты размещались в стерильных чашках Петүи с увлажненным, предварительно прокаленным песком. Чашки закрывались стеклянной пластинкой и устанавливались в темной камере, температура в которой поддержнвалась в пределах 15-20․

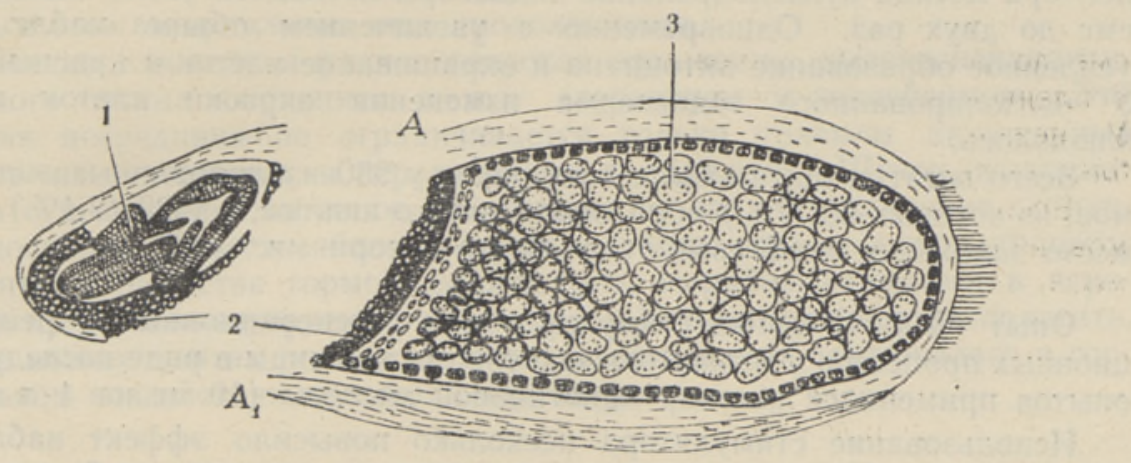

Рис. 1. Схема отделения эндосперма пшеницы от зародыша. $\mathrm{A}-\mathrm{A}_{1}$ - поверхность эндосперма в местах контакта со щитком; 1 - зародыш; 2 - щиток (слева) и остатки клеток щитка (справа); 3 - эндосперм.

После образования на изолянтах адвентивных корней они переносились в световую камеру, с подсветкой люминесцентными лампами, при той же температуре. Перемещение изолянтов обусловливалось тем, что процесс образования адвентивных корней происходит значительно лучше в условиях темноты, а дифференциғовка стеблевой точки роста, по-видимому, на свету.

Развивающиеся впоследствии из заложившихся адвентивных почек ғастенняновообразования пересаживались в бумажные стаканчики с землей н, пробыв несколько дней в обычных комнатных условиях, высаживались в грядки.

\section{Результаты опыта}

Уже в начале работы было подмечено, что при изоляции эндосперма от зародыша и щитка в ряде случаев наблюдается различное состояние поверхности изолянта, т. е. бо́льшая или меньшая ее поврежденность, наличие или отсутствие отдельных групп клеток щитка. В связи с этим возник вопрос о возможном влиянии этих обстоятельств на последующие процессы регенерации. Таким образом возникли два варианта операции: 1) с полностью удаленными остатками щитка и поврежденной поверхностью эндосперма и 2) с умышленно оставленными отдельными группами клеток щитка и только слегка поврежденной поверхностью эндосперма.

Опыт № 1. В результате проведения эксперимента с вышеотмеченными вариантами оказалось, что у 200 изолянтов первого варианта, т. е. с полностью удаленными остатками щитка, заложения почек, корней и даже каллюса не происходило. Во втором варианте, где были оставлены

* Более подробно этн вопросы изложены в работах О.Ф. Михан̆лова $(1951,1952)$. 
отделыные группы клеток щитка, имело место образование каллюса у $5 \%$ (от 200) изолянтов, несколько случаев корнеобразования и только в двух случаях - заложение адвентивных стеблевых почек.

Все изолированные эндоспермы обоих вариантов постепенно увеличивались в объеме, что было следствием как увеличения размеров клеток, так и увеличения их числа в периферических областях эндосперма. Аналогичная картина с увеличением объема эндосперма наблюдалась и на других объектах, например у изолированных эндоспермов клещевины. За полтора месяца культивирования эндосперм последней увеличился в объеме до двух раз. Одновременно с увеличением объема наблюдалось усиленное образование антоциана и окрашивание клеток в красный цвет. y неизолированного эндосперма изменения окраски клеток не наблюдалось.

Всего остатки щитка были сохранены у 930 изолированных эндоспермов, из которых 65 (7\%) образовали только каллюс, а у $22(2,4 \%)$ имело место заложение стеблевых точек роста с корнями.

Опыт № 2. С целью стимулирования регенерационных и репродукционных процессов у изолянтов эндосперма пшеницы в ряде последующих опытов применялся раствор никотиновой кислоты (10 мг на 1 л воды).

Использование стимулятора несколько повысило эффект наблюдаемых явлений. При замачивании зерновок перед операцией раствором никотиновой кислоты $26 \%$ семян образовали каллюс и $8 \%$ - корни (всего было изолировано 200 семян). В этом же опыте у зерновок, замоченных в воде, каллюс образовался у 18 и корни у $4 \%$ семян. Заметного стимулирующего действия никотиновой кислоты на заложение стеблевых точек роста в наших опытах не наблюдалось.

Анализируя проделанные опыты и полученные результаты, можно прийти к твердому убеждению, что эндосперм пшеницы и, по-видимому, других растений, сохраняющийся после вызревания семени, не только не представляет собой мертвый склад запасных питательных веществ, но, наоборот, является весьма активным живым органом, клетки которого обладают довольно высокой потенциальной возможностью. Активная жизнедеятельность клеток эндосперма, в том числе и их потенциальные возможности, не прекращается полностью по мере созревания эндосперма, а лишь постепенно ослабевает. В некоторых наших опытах регенерационные свойства клеток проявлялись и у наполовину опустошенного эндосперма, изолированного во время нормальной физиологической функции последнего на растении $c$-довольно хорошо развитой листовой системой.

Все это, на наш взгляд, подтверждает концепцию ряда авторов о зародышевой природе эндосперма и тем самым способствует выяснению вопроса о механизме возникновения его функций.

Ван-Тигем установил по процессам, происходящим в изолированном эндосперме, наличие двух типов эндосперма: активного, масличного, и пассивного, крахмалистого. Он предполагал, что только эндосперм первого типа обладает способностью к самостоятельной переработке питательных веществ, тогда как второй без участия зародыша на это неспособен. Более поздние исследования показали, что такую разницу между двумя типами установить нельзя. Гринфельд рассматривал эндосперм любого типа как живую ткань. Однако многие исследователи не соглашались с подобным мнением, например Габерланд считал, что у крахмалистого эндосперма живую часть образуют только алейроновый слой и клетки scutellum'a, крахмалистые же клетки являются мертвой тканью. До сих пор, таким образом, этот вопрос оставался открытым. 
Наши данные, как нам кажется, решают вопрос об отсутствии принципиальной разницы в активности и жизнедеятельности клеток эндоспермов масличного и крахмалистого типов.

Проделанные опыты подняли интересный вопрос о роли клеток щитка, остающихся на поверхности эндосперма при удалении зародыша. Являются ли эти остающиеся на эндосперме группы клеток непосредственным источником образования каллюса, а впоследствии - корней и почек, или они выполняют в этом процессе некую косвенную роль? Имеющиеся у нас данные пока не позволяют дать совершенно определенный ответ, опыты в этом направлении еще продолжаются.

Известно, как велика физиологическая роль щитка, высокоспециализированного органа-посредника между зародышем и эндоспермом. Эта функция посредника не ограничивается только приемом питательных веществ из эндосперма и передачей их в зародыш. Щиток оказывает весьма существенное активное воздействие на все составляющие элементы эндосперма. Известна большая роль, которую играют в этом процессе ферменты и вещества гормонального типа, вырабатывающиеся в зародыше и щитке и эвакуируемые в эндосперм. Есть основание предполагать, что и в наших опытах роль оставшихся клеток щитка заключалась в гормональном воздействии на клетки эндосперма.

\section{Растения-новообразования пшеницы и их морфофизиологические особенности}

Вторым аспектом нашей работы являлось выращивание из адвентивных почек эндосперма пшеницы растений-новообразований и описание их морфофизиологических особенностей.

Как уже отмечалось, растения-новообразования пшеницы, достигшие известного развития, а именно способности фотосинтезировать настоящими листьями, высаживались в полевые условия. По мере роста и развития этих растений производились соответствующие фенологические наблюдения и исследовались их морфологические особенности. Во всех случаях, разумеется, имелся.соответствующий контроль.

Опыт № 3. Для получения растений-новообразований был заложен специальный эксперимент по культивированию изолированного эндосперма. В этом опыте исследовалось 1250 изолянтов, из которых у 168 образовались адвентивные стеблевые и корневые точки роста. Однако только в 50 случаях удалось добиться развития жизнеспособного проростка, способного проходить дальнейшее развитие в полевых условиях.

По своему происхождению, т. е. в зависимости от сорта, из зерновок которого они были получены, растения-новообразования разделялись на гри группы: A, В и С. Вариант А - растения-новообразования, полученные из эндосперма Диаманта; вариант В - растения-новообразования из сорта Московка; вариант С - из эндосперма сорта Каука.

Время начала опыта, т. е. заложения изолянтов для культивации, 20 мая, за исключением варианта A, у которого культивирование изолянтов было начато на 15 дней раньше (5 мая).

Цифровые данные, полученные в процессе исследования растений, подвергались обработке методом вариационной статистики.

Уже на первых этапах образования растений из адвентивных почек были отмечены резкие отклонения в развитии по сравнению с растениями из нормальных зерновок. Если у нормальных растений в процессе их развития из пазухи колеоптиле выходит один светло-зеленый лист, то 
при развитии адвентивной почки на поверхности каллюса образуется сразу несколько листьев - от 2 до 5, соответствующих такому же числу самостоятельных побегов (рис. 2). Листья растений-новообразований во всех случаях уже с момента их появления из каллюса обладали яркой зеленой окраской, слегка бледнеющей через несколько дней, но все же остающейся более яркой, чем у нормальных проростков. Приблизительно к 20-му дню часть побегов постепенно засыхала. Таким образом, к этому времени у каждого растения сохранялись только один-два побега, которые продолжали дальнейшее развитие.

В год проведения опытов с нулевым поколением растений-новообразований климатические условия характеризовались повышенной влажностью и низкими средними температурами, что, конечно, сказалось на вегетации всех растений и особенно на новообразованиях. Последние, обладая более длинным вегетационным периодом, заканчивали цикл разви.

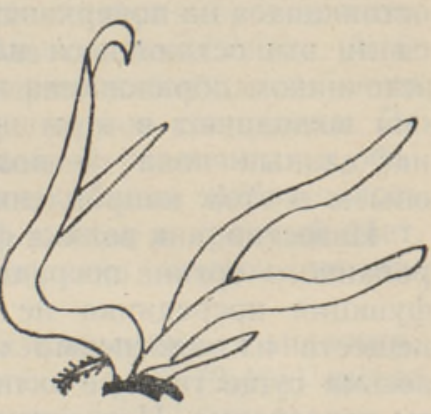

Рис. 2. Растение-новообразование пшеницы через 10 дней после образования адвентивной почки. тия в весьма дождливые и холодные дни, что отразилось и на их урожайности.

Продолжительность вегетационного периода растений-новообразований оказалась на $10-20$ дней больше контрольных (табл. 1).

Продолжительность отдельных фаз развития также

Таблица I

Продолжительность вегетационного периода нулевого поколения (в днях)

\begin{tabular}{l|r|r|r}
\hline \multirow{2}{*}{} & \multicolumn{3}{|c}{ Вариант опыта } \\
\cline { 2 - 4 } & $\mathrm{A}$ & $\mathrm{B}$ & $\mathrm{C}$ \\
\hline Опыт & 116 & 111 & 118 \\
Контроль & 98 & 101 & 98
\end{tabular}

Таблица 2

Продолжительность вегетационного периода первого семенного поколения (в днях)

\begin{tabular}{l|c|c|c}
\hline \multirow{2}{*}{} & \multicolumn{3}{|c}{ Вариант опыта } \\
\cline { 2 - 4 } & A & B & C \\
\hline Oпыт & 103,3 & 106,6 & 109,0 \\
Контроль & 107,5 & 115,3 & 119,2
\end{tabular}
несколько удлинялась, однако наибольшее отставание растений-новообразований от контроля происходило в период между появлением третьего настоящего листа и началом кущения.

В первом семенном поколении, полученном в следующем году, продолжительность вегетационного периода растений-новообразова ний уменьшилась как в абсолютном значении, так и по сравнению с контролем (табл. 2).

Сокращение вегетационного периода у первого семенного поколения не происходило равномерно по всем фазам развития. Фазу развития «от появления третьего настоящего листа до начала кущения» растения-новообразования закончили раньше контроля на 1 день; фазу «от начала цветения до молочной спелости» - на $1-2$ дня раньше контроля и фазу «от молочной спелости до восковой спелости» - на 2,5-6 дней раньше контроля. Остальные фазы развития опытных и контрольных растений первого семенного поколения не отличались друг от друга.

В нулевом поколении растений-новообразований высота стебля и его 
диаметр были меньше контрольных (за исключением диаметра в варианте А), причем отмечалось большое количество карликовых форм (табл. 3). Коэффициент изменчивости обоих признаков у опытных растений несколько больший, чем у контрольных.

Высота и диаметр стебля у растений нулевого поколения

Таблица 3

\begin{tabular}{|c|c|c|c|c|c|c|c|c|}
\hline \multirow{3}{*}{ 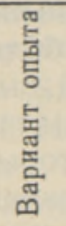 } & \multicolumn{4}{|c|}{ Высота стебля } & \multicolumn{4}{|c|}{ Диаметр стебля } \\
\hline & \multicolumn{2}{|c|}{ CM } & \multicolumn{2}{|c|}{$\mathrm{V}, \%$} & \multicolumn{2}{|c|}{$\mathrm{cm}$} & \multicolumn{2}{|c|}{$\mathrm{V}, \%$} \\
\hline & Опыт & Контроль & Опыт & Контроль & Oпыт & Контроль & Опыт & Контроль \\
\hline $\begin{array}{l}\mathrm{A} \\
\mathrm{B} \\
\mathrm{C}\end{array}$ & $\begin{array}{l}66,2 \pm 3,7 \\
78,2 \pm 4,0 \\
73,3 \pm 9,3\end{array}$ & $\begin{array}{l}77,0 \pm 5,2 \\
94,8 \pm 1,7 \\
90,8 \pm 1,7\end{array}$ & $\begin{array}{l}15,6 \\
17,3 \\
18,9\end{array}$ & $\begin{array}{l}18,1 \\
12,9 \\
13,4\end{array}$ & $\begin{array}{l}3,6 \pm 0,2 \\
3,5 \pm 0,2 \\
4,3 \pm 0,2\end{array}$ & $\begin{array}{l}3,5 \pm 0,1 \\
3,7 \pm 0,1 \\
4,6 \pm 0,1\end{array}$ & $\begin{array}{r}19,2 \\
16,3 \\
6,6\end{array}$ & $\begin{array}{l}14,8 \\
12,6 \\
16,1\end{array}$ \\
\hline
\end{tabular}

В первом семенном поколении отмечалось выравнивание величин высоты стебля и его диаметра у опытных и контрольных растений. Коэффициент изменчивости в этом случае был невелик как у опытных, так и у контрольных форм и колебался в пределах $10-11 \%$.

Как уже отмечалось, растения-новообразования уже в начальный момент своего развития проявили тенденцию к кущению, что в известной степени сохранилось и у взрослых форм. Однако оказалось, что число плодоносящих побегов у нулевого поколения растений-новообразований несколько меньше, чем у контрольных. То же имело место и относительно величины колоса. Коэффициент изменчивости этих признаков у опытных растений был сравнительно велик и больше, чем у контроля.

В первом семенном поколении число плодоносящих побегов и величйна колоса как у опытных, так и у контрольных растений практически не отличались друг от друга, за исключением варианта В, у которого размеры колоса опытных растений оказались больше, чем у контроля (у опытных растений длина колоса - 9,4 $\pm 0,4$ см, диаметр колоса $11,5 \pm 0,4$ мм; у контрольных длина колоса $-8,6 \pm 0,2$ см, диаметр $10,2 \pm 0,2 \mathrm{мм})$.

При определении у растений числа колосков и числа зерен в колосе наблюдался значительно бо́льший разнобой в данных, чем у вышерассмотренных признаков. При этом следует отметить, что в нулевом поколении картина более ровная. В данном случае абсолютная величина этих признаков у контрольных растений была несколько выше, чем у опытных форм. Однако коэффициент изменчивости у последних немного превышал таковой у контроля (табл. 4).

Таблица 4

Количество и вес зерен одного колоса у нулевого поколения растений

\begin{tabular}{|c|c|c|c|c|c|c|c|c|}
\hline \multirow{3}{*}{ 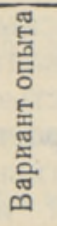 } & \multicolumn{4}{|c|}{ Количество зерен } & \multicolumn{4}{|c|}{ Вес зерен } \\
\hline & \multicolumn{2}{|c|}{ шт. } & \multicolumn{2}{|c|}{$\mathrm{V}, \%$} & \multicolumn{2}{|c|}{$\mathrm{r}$} & \multicolumn{2}{|c|}{$\mathrm{V}, \%$} \\
\hline & Опыт & Контроль & Опыт & Контроль & Опыт & Контроль & Опыт & Контроль \\
\hline $\begin{array}{l}\text { A } \\
\text { B } \\
\text { C }\end{array}$ & $\begin{array}{l}23,3 \pm 2,8 \\
21,5 \pm 2,1 \\
21,0 \pm 2,6\end{array}$ & $\begin{array}{l}28,9 \pm 1,0 \\
25,6 \pm 1,3 \\
29,0 \pm 1,3\end{array}$ & $\begin{array}{l}44,5 \\
45,0 \\
30,6\end{array}$ & $\begin{array}{l}23,5 \\
34,8 \\
31,1\end{array}$ & $\begin{array}{l}0,76 \pm 0,11 \\
0,59 \pm 0,08 \\
0,32 \pm 0,09\end{array}$ & $\begin{array}{l}0,91 \pm 0,04 \\
0,75 \pm 0,05 \\
0,91 \pm 0,07\end{array}$ & $\begin{array}{l}52,6 \\
62,7 \\
65,6\end{array}$ & $\begin{array}{l}33,7 \\
44,2 \\
50,5\end{array}$ \\
\hline
\end{tabular}


В первом семенном поколении среднее количество зерен в колосе и средний вес зерен одного колоса мало отличались у контроля и опыта. Однако степень изменчивости этих признаков у растений-новообразований значительно выше и колебалась в пределах $30-60 \%$.

Наибольший интерес представляют данные о весе 1000 зерен, характеризующие как величину и наполненность зерен, так и урожайность растений. В нулевом поколении, как правило, этот показатель был меныше, чем у контроля, однако встречались и существенные отклонения в бо́льшую сторону. В варианте же А вес 1000 зерен у опытных растений был больше контроля. Последнее объясняется, по-видимому, более ранним посевом этого варианта и, следовательно, лучшими условиями, в которых находились растения в конце

Таблица 5

Вес 1000 зерен у растений нулевого поколения (в граммах)

\begin{tabular}{l|c|c|c}
\hline \multirow{2}{*}{} & \multicolumn{3}{|c}{ Вариант опыта } \\
\cline { 2 - 4 } & $\mathrm{A}$ & $\mathrm{B}$ & $\mathrm{C}$ \\
\hline \multirow{3}{*}{ Опыт } & $32,2 \pm 2,6$ & $25,5 \pm 1,3$ & $18,3 \pm 8,1$ \\
Контроль & $30,8 \pm 1,0$ & $28,6 \pm 1,0$ & $30,0 \pm 1,4$
\end{tabular}

таблица 6 ления. В данном случае вес

Вес 1000 зерен растений первого семенного поколения (в граммах)

\begin{tabular}{l|c|c|c}
\hline \multirow{2}{*}{} & \multicolumn{3}{|c}{ Вариант опыта } \\
\cline { 2 - 4 } & A & B & C \\
\hline Oпыт & $44,8 \pm 1,0$ & $36,7 \pm 0,9$ & $35,7 \pm 1,6$ \\
Контроль & $42,8 \pm 0,6$ & $29,9 \pm 0,6$ & $36,3 \pm 0,6$
\end{tabular}
поколения был произведен сравнительно поздно, что неблагоприятно сказалось на процессе созревания урожая. Изменчивость этого признака как у контрольных, так и у опытных растений примерно одинакова (табл. 5).

Иная картина наблюдается у первого семенного поко1000 зерен у вариантов А и В больше, чем у контроля, а y варианта C практически не отличается от последнего. Коэффициент изменчивости этого признака у растений семенного поколения как у контроля, так и у опыта нецикла развития. Посев двух других вариантов нулевого велик и колеблется от 7 до $14 \%$ (табл. 6).

Анализ полученных данных по урожайности показывает, что степень достоверности различия вариантов А и С невелика. Что же касается варианта В, го его данные вполне достоверны и представляют известный интерес, в связи с чем нами предпринято изучение ряда других поколений этой формы растений-новообразований. Кроме того, намечено проведение испытаний семенных поколений растений-новообразований по ряду других ценных с хозяйственной точки зрения признаков.

\section{Выводы}

1. Әндосперм пшеницы не представляет собой только склад запасных питательных веществ, но обладает живыми, достаточно активными клетками, обладающими сравнительно высокой потенциальной возможностью.

2. Потенциальные возможности .клеток эндосперма пшеницы проявляются в увеличении их объема и делении (размножении) при культивировании эндосперма в изолированном виде, а также в вытекающей из этого способности регенерировать отдельные органы и репродуцировать весь организм растения в целом.

3. При соответствующих условиях культивирования эндосперма имеют место такие проявления жизнедеятельности его клеток, которые свиде- 
тельствуют о неправильном разделении эндоспермов на два принципиально различных типа - пассивный и активный (крахмалистый и масличный). Наши данные свидетельствуют о том, ччто не только масличный, но оба типа эндосперма обладают живыми, активными клетками.

4. Полученные данные о жизнедеятельности, активности и потенциальных возможностях клеток эндосперма являются косвенным подтверждением концепции ряда исследователей о зародышевой природе этого органа.

5. Результаты проведенных исследований подтверждают точку зрения И. И. Презента о специфической роли эндосперма, выполняющего функцию своеобразного биологического ментора на пути становления у развивающегося растения видовых и сортовых признаков.

6. Дифференцирующиеся в каллюсе изолированного эндосперма почки развиваются в растения-новообразования, отличающиеся рядом морфофизиологических особенностей.

7. Растения-новообразования, пшеницы, судя по ряду морфофизиологических показателей и большим величинам коэффициентов изменчивости, обладают неустановившейся, расшатанной наследственностью, особенно в нулевом поколении.

8. Растения-новообразования пшеницы могут представлять интерес для селекции как исходные формы, обладающие некоторыми полезными хозяйственными признаками.

\section{Л ИТЕ Р АТ У РА}

Александров В. Г., Яковл ев М. С., 1935. Морфология зерна и строенне эндосперма различных форм кукурузы. Ботан. ж. СССР, т. 20.

Ал ександров В. Г., 1937. Анатомия растений. М.

Александров В. Г., 1945. К вопросу о двойном оплодотвореннн. Успехн соврем. бнол., т. 22.

Александров В. Г., 1954. Анатомия растений. М.

Алявдина А. А., 1937. Микроскопическое исследование прорастающих семян и отделенного эндосперма Linum Ussitatissimum L. Ботан. ж. СССР, т. 22.

М и х ай ло в О. Ф., 1951. Морфогенез новообразований подсолнечника и гороха, полученных на изолированных семядолях. Уч. зап. ЛГУ, Сер. бнол, наук, № 139, вып. 26.

Ми х а йлов О. Ф., 1952. Биологическая специфика семядолей в семенах растений, не сохраняющих эндосперм. Научн, тр., посвященные 150-летию Тартуск. гос. ун-та. Таллин.

М и х а йл о в О. Ф., 1957а. Метод культуры тканей и получение 'новых форм растений. Уч. зап. Тартуск, гос. ун-та, вып. 46.

М и х айлов О. Ф., 19576. К вопросу о филогенетическом значении явления регенерации у растений. Уч. зап. Тартуск. гос. ун-та, вып, 46.

Мих а й лов О. Ф., 1958. Проблема детерминации и патологический морфогенез растений. Уч. зап. Тартуск. гос, ун-та, вып, 64.

Мнх ай лов О. Ф., 1959. Метод культуры растительных тканей и формообразовательные процессы. В сб. Наследственность и изменчивость растений, животных и микроорганизмов, Тр. конф., посвящ. 40-летию Великой Октябрьской социалистической революции, т. II. Изд. АН СССР. М.

Модилевский Я. С., 1950. Современное состояние вопроса об эндосперме у покрытосемянных растений в связи с формированием зародыша, семени и плода. Изв. АН СССР, Сер. бнол., № 2.

Н а в а ш и н С. Г., 1898. Новые наблюдения над оплодотворением у Fritillaria tenella и Lilium Martagon. Дневн, Х Съезда русск. естествоисп. и врачей, № 6.

О р а в Т. А., 1959. О культуре изолированного эндосперма. В сб. Наследственность и изменчивость растений, животных и микроорганизмов, Тр. конф., посвящ. 40-летию Великой Октябрьской социалистической революцин, т. II. Изд. АН CCCP. $M$. Презент И. И., 1948. Биологическое значение двойного оплодотворення. Агробноло-
гия, № 5. 
B lociszewski, Th., 1876. Physiologische Untersuchungen über die Keimung und weitere Entwicklung einiger Samenteile bedecktsamiger Pflanzen. Landwirtsch. Jahrb., Bd. V.

Petr ū, E., Ř e tov sky̆, R., 1956. Rostlinné Explantáty. Nạklad, Ceskcsl. Akad. vĕd. Praha.

Puriewitsch, K., 1898. Physiologische Untersuchungen über die Entleerung der Reservestoffbehälter. Jahrb. f. wiss. Bot., Bd. XXXI.

V a n T i eghem, Ph., 1873. Recherches Physiologiques sur la Germination. Ann. des Sci. Natur., Sér. 5., T. XVII.

Тартуский государственный университет
Ннститут экспериментальной биологии
Академии наук Эстонской ССР Поступнла в редакцню 13 III 1959

\title{
EEMALDATUD LOOTEGA NISUTERISTEST KASVANUD TAIMED JA NENDE MORFOFUSIOLOOGILISI ISEARASUSI
}

\author{
0. Mihhailov, \\ biolooglateaduste kandidaat
}

T. Orav

Resümee

Artiklis kāsitletakse taimede uudismoodustiste saamise vōimalikkust kōrvaldatud lootega nisuteristel tekkinud adventiivpungadest. Selle küsimusega on tihedasti seotud ka mitmed endospermi ja kilbikese funktsiooni ning pōlvnemise teoreetilised probleemid.

Tartu Riikliku Ulikooli Bioloogiajaamas teostatud katsetes kasutati objektina Triticum vulgare kolme suvisorti: 'Diamant' (T. vulgare var. milturum), 'Kauka' (var. lutescens) ja 'Moskovka' (var. graecum).

Steriilsetes tingimustes eemaldati leotatud teristelt prepareerimisnōela abil loode koos kilbikese pōhimassiga. Endosperme kultiveeriti Petri tassides steriilses liivas, mis paigutati pimedusse ja hoiti kindla temperatuuri juures. Neis tingimustes tekkisid osal isolantidel adventiivpungad. Viimastest kasvanud taimede morfogeneesi uuriti põllutingimustes.

Nisuterise adventiivpungadest kasvanud uudismoodustised erinevad, eriti varajasematel arenguetappidel, normaalsetest nisutaimedest tunduvalt. Erinevused seisnesid mitme lehe esinemises uudismoodustistel nende kõige varajasemal arenguperioodil ja silmapaistvalt intensiivsemas rohelises värvuses. Morfolcogiliste tunnuste statistiline analüüs näitas uudismoodustiste tunduvalt tugevamat muutlikkust, vōrreldes normaalsete taimedega.

Katsete tulemused võimaldavad teha allpool esitatavaid järeldusi:

1) Nisu endosperm ei kujuta endast mitte ainult varuainete panipaika, vaid omab ka elusaid ja küllaltki aktiivseid rakke, millel on võrdlemisi suured potentsiaalsed võimalused edasiseks kasvuks ja arenguks.

2) Nisu endospermi rakkude potentsiaalsed vōimalused avalduvad nende kasvamises ja jagunemises (paljunemises) endospermi isoleeritud kasvatamisel ning võimes regenereerida üksikuid organeid ja reprodutseerida kogu taimorganismi tervikuna.

3) Kindlates kultiveerimistingimustes esinevad endospermi rakkudel sellised elutegevuse nähtused, mis osutavad, et endospermi jagamine kaheks printsipiaalselt erineváks tüübiks - passiivseks ja aktiivseks (tärklist sisaldavaks ja ölikaks) on öigustamata. Meie katseandmed näitavad, et mōlemad endospermi tüübid omavad elusaid aktiivseid rakke.

4) Meie andmed endospermi rakkude elutegevuse, aktiivsuse ja potentsiaalsefe vōimaluste kohta on selle organi lootelise loomuse kontseptsiooni kaudseks kinnituseks.

5) Uurimistulemused kinnitavad I. Presenti kontseptsiooni endospermi spetsiifilisest tähtsusest, mis etendab omalaadse bioloogilise mentori osa areneva taime liigi- ja sorditunnuste tekkimisel.

6) Isoleeritud endospermi kalluses tekkivatest adventiivpungadest arenevad taimed erinevad normaalsetest rea morfofüsioloogiliste iseärasuste poolest.

7) Otsustades rea morfofüsioloogiliste näitajate ja muutlikkuskoefitsientide suurenemise järgi osutub, et nisutaimede uudismoodustistel on ebapüsiv, kõigutatud pärilikkus, eriti nullpōlvkonnas.

8) Majanduslikult kasulike tunnuste esinemise tõttu võivad pakkuda nisutaimede uudismoodustised huvi selektsiooni lähtematerjalina.

Tartu Riiklik Olikool,

Eesti NSV Teaduste Akadeemia

Eksperimentaalbioloogia Instituut
Saabus toimetusse

13. III 1959 


\title{
PLANTS GROWN OF WHEAT SEEDS WITH REMOVED EMBRYONS AND THEIR MORPHOPHYSIOLOGICAL PECULIARITIES
}

\author{
O. Mikhailov, T. Orav
}

Summary

The authors deal with the possibility of novel formations of plants grown of adventive buds developed of wheat seeds with removed embryons. This question is closely connected with several others, such as the problem of the function of the endosperm and the scutum, and the theoretical problems of generation.

At the Biological Station of the Tartu State University three summer varieties of Triticum vulgare were used for experiments: 'Diamant' (T. vulgare var. milturum), 'Kauka' (var. lutescens) and 'Moskovka' (var. graecum).

In sterile conditions, the embryon together with the main mass of the scutum was removed with a preparation needle. The endosperms were cultivated on sterile sand in Petri cups placed in the dark, and kept at a constant temperature. In the above conditions part of isolants developed adventive buds. The morphogenesis of the plants grown of these buds was investigated in field conditions.

The novel formations grown of adventive buds of wheat seeds differed from the normal plants to a considerable extent, especially at the early stages of development. The difference consisted in the occurrence of several leaves on the novel formations at the very earliest stage of development, and in their far more intensive, strikingly green colouring. A statistic analysis of the morphological properties revealed a considerably greater mutability of the novel formations, if compared to the normal plants.

The results of experiments allow the authors to draw the following conclusions:

1) The wheat endosperm is not only a receptacle for supplies, but it also contains living and sufficiently active cells with great potentialities for further growth and development.

2) The latent potentialities of wheat endosperm cells become apparent in their growth and division (multiplication) at the isolated cultivation of the endosperm, as well as in their ability of regenerating single organs and reproducing the plant organism as a whole.

3) In certain conditions of cultivation, the endosperms reveal such phenomena of vital activity that show that the dividing of endosperms into two fundamentally different types - the passive and the active type (the starch-containing and the oily one) is not justified. The experiments carried out by the authors reveal that both types of endosperms have living, active cells.

4) The data on the vital functions, activity and potentialities of the cells of the endosperm are an indirect proof of the embryonic character of that organ.

5) The experimental data confirm I. Present's conception of the specific significance of the endosperm playing the part of a distinctive biological mentor at the formation of the properties of species and variety of the developing plant.

6) The plants developed of adventive buds generated in the callus of the isolated endosperm differ from the normal ones in a number of morphophysiological peculiarities.

7) Considering a number of morphophysiological indicators as well as the increase of the mutability coefficients, it appears that the novel formations of wheat plants have an inconstant, unstable heredity, and that particularly in the zero-generation.

8) Considering the economic expediency of the properties of the novel formations of wheat plants, the latter may be of some interest as an object for effecting selection.

Tartu State University,

Academy of Sciences of the Estonian S.S.R., Institute of Experimental Biology
Received March 13th, 1959 